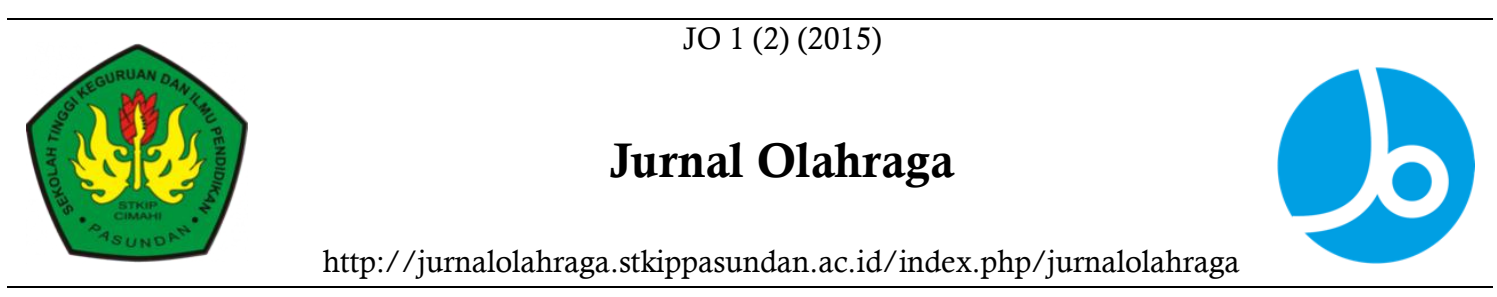

\title{
Pengembangan Model Passing Bawah Bolavoli melalui Pendekatan Permainan Tradisional Gatrik di SMPN 3 Parongpong Kabupaten Bandung Barat
}

\begin{tabular}{|c|c|}
\hline & $\begin{array}{c}\text { Aep Rohendi } \\
\text { STKIP Pasundan, Indonesia }\end{array}$ \\
\hline Info Artikel & Abstrak \\
\hline $\begin{array}{l}\text { Sejarah Artikel: } \\
\text { Diterima Agustus } 2015 \\
\text { Disetujui Oktober } 2015 \\
\text { Dipublikasikan Oktober } 2015\end{array}$ & $\begin{array}{l}\text { Penelitian ini bertujuan untuk mengembangkan suatu model passing } \\
\text { bawah Bola Voli melalui pendekatan gerak dasar permainan } \\
\text { tradisional gatrik.Penelitian ini dilaksanakan di SMPN III } \\
\text { Parongpong Kabupaten Bandung Barat. Penelitian dan } \\
\text { pengembangan model pembelajaran ini menggunakan } \\
\text { metodepenelitian pengembangan Research \& develoment (R \& D). } \\
\text { Penelitian ini dilakukan dengan } 8 \text { langkah, pertama kali yang di } \\
\text { tentukan adalah sebuah ide yang akan dikembangkan, kedua } \\
\text { rancangan produk, ketiga evaluasi untuk memperbaiki dan } \\
\text { menyempurnakan naskah, ke empat revisi produk I, dilalukan oleh } \\
\text { ahli yang bersangkutan, ke lima produk prototipe, dilakukan dengan } \\
\text { pengambilan gambar produk, ke enam Uji coba prototipe, pengujian } \\
\text { terhadap subyek lapangan baik dalam uji coba tahap I maupun tahap } \\
\text { II, ke tujuh revisi produk kedua, revisi dilakukan oleh ahli, ke } \\
\text { delapan reproduksi, penyempurnaan produk untuk menuju produk } \\
\text { akhir. Dari tahapan-tahapan tersebut maka didapatkan hasil dari } \\
\text { penelitian tersebut dengan analisis evaluasi tahap pertama dengan } \\
\text { sepuluh produk di hasilkan total sekor responden diperoleh jumlah } \\
\text { data = 123 Dengan demikian efektifitas metode mengajar baru } \\
\text { secara keseluruhan = } 123: 144=0,85 \text { atau } 85 \% \text { dari kreteria yang } \\
\text { diharapkan dan berdasarkan analisis evaluasi tahap ke II dengan } \\
\text { menggunakan produk final berjumlah maka yang dihasilkan total } \\
\text { skor responden. diperoleh jumlah data = 246. Dengan demikian } \\
\text { efektivitas metode mengajar secara keseluruhan = 246:288 = } 0,85 \\
\text { atau 85\% dari kriteria yang di harapkan sehingga memenuhi } \\
\text { kreteria valid. Berdasarkan hasil penelitian tersebut maka dapat } \\
\text { disimpulkan bahwa: (1) Dengan model pembelajaran passing bawah } \\
\text { bolavoli melalui pendekatan permainan tradisional gatrik di Sekolah } \\
\text { Menengah Pertama, sangat dibutuhkan oleh para guru pendidikan } \\
\text { jasmani serta mampu meningkatkan belajar secara efektif dan } \\
\text { efisien. (2) dengan model pembelajaran yang telah peneliti } \\
\text { kembangkan, siswa lebih termotivasi serta aktif dalam mengikuti } \\
\text { proses pembelajaran. }\end{array}$ \\
\hline
\end{tabular}




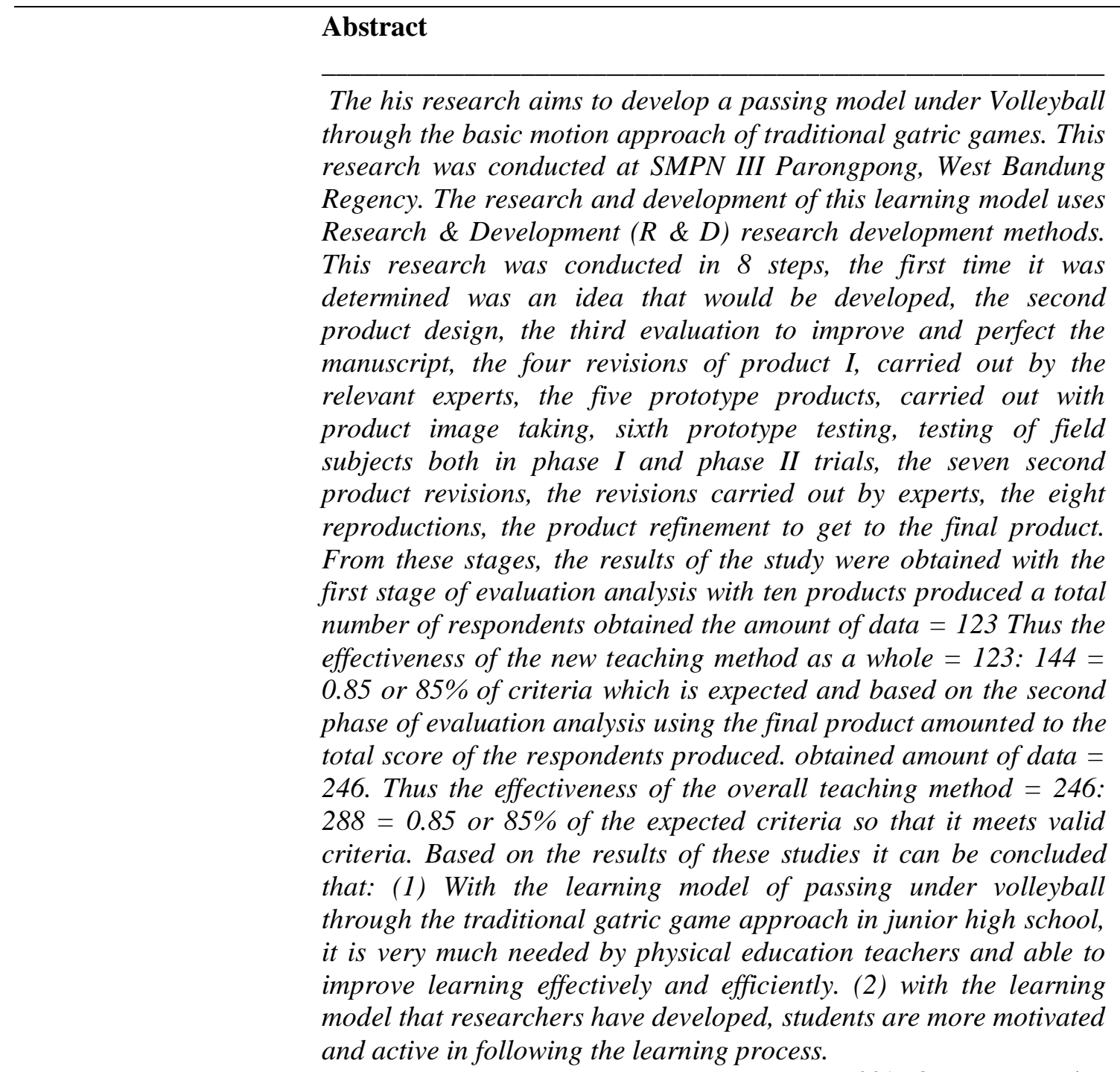

(C) 2015 STKIP Pasundan

Under the license CC BY-SA 4.0

\footnotetext{
Alamat korespondensi:

E-mail: aeprohendi22@gmail.com
}

\section{PENDAHULUAN}

Pendidikan jasmani merupakan suatu bagian dari pendidikan umum. Lewat pembelajaran pendidikan jasmani dapat diupayakan peranan pendidikan untuk mengembangkan kepribadian individu. Mata pelajaran Penjaskes yang diajarkan dari jenjang pendidikan dasar sampai pendidikan menengah dan perguruan tinggi melalui aktivitas fisik. Pendidikan jasmani diharapkan dapat mendorong pertumbuhan fisik, perkembangan psikis, keterampilan
ISSN 2442-9661 (cetak)

motorik, pengatahuan dan penalaran, penghayatan nilai-nilai (sikap, mental, emosional sportivitas, spiritual, sosial), serta pembiasaan hidup sehat untuk merangsang pertumbuhan dan perkembangan kualitas fisik dan psikis yang seimbang.

Pendidikan jasmani merupakan sebuah investasi jangka panjang dalam upaya pembinaan mutu sumberdaya manusia Indonesia. Hasil yang diharapkan itu akan tercapai setelah masa yang cukup lama. Upaya pembinaan warga masyarakat dan 
peserta didik melaui pendidikan jasmani membutuhkan kesabaran dan keikhlasan untuk berkorban. Pembinaan mutu sumber daya manusia Indonesia dapat diupayakan melalui pendidikan jasmani di lembaga pendidikan formal dan non farmal dapat berkembang lebih pesat yang dapat menjadi landasan bagi pembinaan keolahragaan nasional.

Sumbangan nyata pendidikan jasmani adalah untuk mengembangkan keterampilan (psikomotor) khususnya dengan tidak mengabaikan aspek kognitif dan afektif. Dengan demikian proses pendidikan jasmani menjadi unik. Hal ini sekaligus mengungkapkan kelebihan pendidikan jasmani dari pelajaran lainnya. Jika matapelajaran lain lebih mementingkan perkembangan intelektual, maka melalui pembelajaran penjas sekaligus membina aspek sikap dan keterampilan. Terdapat tiga hal penting yang bisa menjadi sumbangan unik dari pendidikan jasmani, yaitu: Meningkatkan kebugaran jasmani dan kesehatan siswa, meningkatkan keterkuasainya fisik yang kaya, sertameningkatkan pengertian siswa dalam prinsip gerak serta bagian menerapkannya dalam praktek.

Pendidikan jasmani adalah olahraga yang dilakukan di lingkungan sekolah, menurut pasal 18 dalam undang-undang siskormas ayat 1 dan 2 pendidikan jasmani diselenggarakan sebagai proses pendidikan dan ayat 2 pendidkan jasmani dilaksanakan baik pada jalur pendidikan formal maupun nonformal melalui kegiatan intrakulikuler dan ekstrakurikuler. Pelaksanaan pendidikan jasmani secara intrakurikuler diberi alokasi waktu 3 jam pelajaran per minggu sedangkan pelaksanaan pendidikan jasmani secara extrakurikuler disesuaikan dengan kebutuhan.

Permainan merupakan salah satu bentuk kegiatan dalam pendidikan jasmani. Dengan permainan dapat membangun nilai- nilai sosial yang terkandung, misalnya kebersamaan, menghargai perbedaan, kekompakan, kejujuran, menerima kelebihan lawan atau tim lain untuk mewujudkan lahirnya pribadi-pribadi unggul yang bermartabat. Selainhal itu permainan adalah salah satu media yang dahsyat untuk menyehatkan, membugarkan dan mencerdaskan siswa.

Permainan yang sudah menjadi gaya hidup dalam kehidupan sehari-hari di lingkungan sekolah salah satunya olahraga bolavoli. Olahraga bolavoli tidak lepas dari ketersediaan sarana dan prasarana yang memadai sehingga bisa tersalurkan setiap minat dan bakat siswa yang baik, keinginan atau minat yang kuat dari setiap siswa yang menyukai permainan bolavoli.

Passing dalam bolavoli merupakan salah satu indikator sub kompetensi dasar dari mempraktekan gerak dasar permainan bola besar sederhana dengan peraturan yang dimodifikasi serta nilai kerja sama, sportivitas dan kejujuran merupakan salah satu materi yang harus diajarkan, pada pelaksanaannya harus mengacu pada muatan tujuan pendidikan jasmani diantaranya mengembangkan keterampilan pengelolaan diri dalam upaya meningkatkan keterampilan gerak melalui berbagai aktivitas jasmani dan olahraga yang terpilih. Selain itu juga dinyatakan tujuan pendidikan jasmani adalah memahami konsep aktivitas jasmani dan olahraga di lingkungan yang bersih sebagai informasi untuk mencapai pertumbuhan fisik yang sempurna, pola hidup sehat dan kebugaran, terampil, serta memiliki sikap yang positif.

Passing bawah sangat penting bagi anak-anak karena merupakan gerakan yang sangat mendasar di dalam permainan bolavoli, pasing bawah digunakan untuk menerima servis, spike, yang diarahkan dengan keras, bola-bola pendek, dan bola yang mengarah kejaring. Selain itu, ditingkat 
remaja (dan dalam situasi darurat disemua tingkat), passing bawah bisa digunakan untuk memberikan umpan ke penyerang. Khususnya ketika pasing ke pengumpan terlalu rendah untuk diumpankan dengan menggunakan passing atas. Passing bawah merupakan jenis passing paling umum yang digunakan dalam bolavoli, semua pemain harus mempelajari cara melakukan passing bawah karena siswa akan berotasi melewati semua posisi dilapangan.

Pelaksanaan pelajaran bolavoli untuk anak sekolah menengah pertama seharusnya berbeda dengan yang dilakukan pada orang dewasa, karena permainan ini perlu disesuaikan dengan kondisi fisik dan psikologis anak. Pengembangan permainan dapat dilakukan dengan perubahan pada aturan sekunder seperti ukuran lapangan, berat atau jenis peralatan, area bermain, lama permainan, aturan permainan, jumlah pemain dalam tim, ukuran sasaran dasar, dan metode penelitian.

Struktur permainan dapat dilakukan terhadap faktor : 1) ukuran lapangan, 2) bentuk, ukuran, dan jumlah, 3) peralatan yang digunakan, 4) jenis skill yang digunakan, 5) aturan, 6) jumlah pemain, dan 7) organisasi pemain, dan tujuan permainan.

\section{METODE}

Dalam penelitian pengembangan model Passing bolavoli melalui gerak dasar permainan tradisional gatrik pada anak sekolah menengah pertama ini merupakan suatu proses yang digunakan untuk mengembangkan dan memvalidasi produk pembelajaran. Penelitian dan pengembangan dalam pembelajaran ini menggunakan model pengembangan Research \& develoment (R \& D) dari Borg dan Gall yang terdiri dari sepuluh langkah antara lain: (1) Melakukan penelitian dan pengumpulam informasi (kajian pustaka, pengamatan subyek, persiapan laporan pokok persoaalan). (2) melakukan perencanaan (pendefinisian keterampilan, perumusan tujuan, penetuan urutan pengajaran, dan uji coba skala kecil). (3) mengembangkan bentuk produk awal (penyiapan materi pengajaran, penyusunan buku pegangan, dan pelengkapan evaluasi). (4) melakukan uji lapangan permulaan (menggunakan 6 - 12 subyek) melakukan revisi terhadap produk utama (sesuai dengan saran-saran dari hasil uji lapangan permulaan) (6) melakukan uji lapangan utama (dengan 30-100 subyek) (7) melakukan revisi produk (berdasarkan saransaran dan hasil uji coba lapangan utama) (8) uji lapangan dengan 40-200 subyek (9) revisi produk akhir (10) membuat laporan menganai produk pada jurnal, bekerja dengan penerbit yang dapat melakukan distribusi secara komarsial.

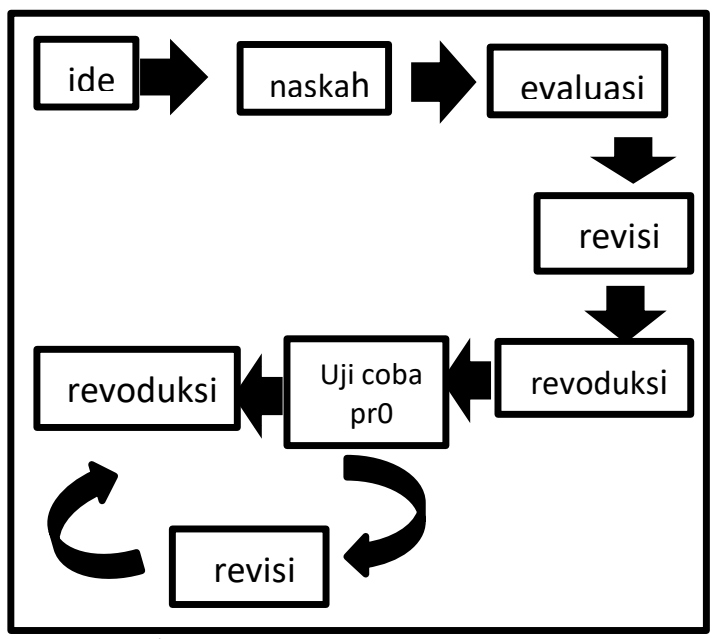

Gambar`1. Model Pengembangan dengan Flow Chart

Sumber: Sadiman, Arif. S. Media Pendidikan Pengertian, Pengembangan, dan Pemampaatannya (Jakarta: Pustekom Dikbud, 2003)

(1) Pertama kali yang di tentukan adalah sebuah ide-ide yang akan dikembangkan, dengan mengumpulkan informasi sebagai landasan pemikiran untuk membuat konsep (2) Evaluasi ini dilakukan untuk memperbaiki dan menyempurnakan naskah yang telah dibuat. (3) Revisi produk I, revisi dilalukan oleh ahli yang bersangkutan, 
(4) Produk prototipe, dilakukan dengan pengambilan gambar produk dengan media audio-visual (video), (5) Uji coba prototipe, pengujian terhadap subyek lapangan baik dalam uji coba tahap I maupun tahap II, (6) Revisi produk kedua, revisi dilakukan oleh ahli guna memperoleh hasil sempurna. (7) Reproduksi, penyempurnaan produk untuk menuju produk akhir yang diharapkan pada pengembangan.

\section{HASIL DAN PEMBAHASAN}

Data penilaian dari 12 responden/siswa terhadap efektivitas metode mengajar lama ditunjukan pada tabel 1 dan metode mengajar baru ditunjukan tabel 2 berikut ini:

Tabel 1. Hasil Penilaian dengan Metode

\section{Lama}

\begin{tabular}{|l|c|c|c|c|}
\hline \multirow{2}{*}{ No } & \multicolumn{3}{|c|}{ Penilaian } & \multirow{2}{*}{ Jumlah } \\
\cline { 2 - 5 } & \multicolumn{3}{|c|}{ Passing bawah } \\
\hline & $\begin{array}{c}\text { Sikap } \\
\text { awal }\end{array}$ & $\begin{array}{c}\text { Gerak } \\
\text { lanjutan }\end{array}$ & $\begin{array}{c}\text { Gerak } \\
\text { akhir }\end{array}$ & \\
\hline 1 & 1 & 2 & 2 & 5 \\
\hline 2 & 2 & 1 & 2 & 5 \\
\hline 3 & 2 & 2 & 3 & 7 \\
\hline 4 & 1 & 3 & 2 & 6 \\
\hline 5 & 1 & 2 & 3 & 6 \\
\hline 6 & 2 & 3 & 1 & 6 \\
\hline 7 & 2 & 2 & 3 & 7 \\
\hline 8 & 3 & 2 & 2 & 7 \\
\hline 9 & 2 & 1 & 3 & 6 \\
\hline 10 & 1 & 2 & 3 & 6 \\
\hline 11 & 2 & 2 & 1 & 5 \\
\hline 12 & 2 & 2 & 2 & 6 \\
\hline Jumlah & $\mathbf{2 1}$ & $\mathbf{2 4}$ & $\mathbf{2 7}$ & $\mathbf{7 2}$ \\
\hline$\%$ & $44 \%$ & $50 \%$ & $56 \%$ & $50 \%$ \\
\hline
\end{tabular}

Untuk menghitung rata-rata efektivitas metode lama dan baru pertama-tama harus ditentukan skor kriterium/ideal untuk sistem kerja tersebut.

Skor ideal = 1 X 3 X 4 X $12=144$ dimana, $1=$ skor jawaban tertinggi

3 =tahapan gerak (sikap awal, gerak lanjutan, gerak akhir)

4 = butir soal
12 = jumlah responden

Selanjutnya skor ideal setiap butir instrumen $=1 \times 4 \times 12=48$ dimana,

$1=$ skor jawaban tertinggi

4 = tahapan gerak

$12=12$ jumlah responden

Berdasarkan tabel 1 diperoleh jumlah data $=72$. Dengan demikian efektifitas metode mengajar lama secara keseluruhan $=$ $72: 144=0,50$ atau $50 \%$ dari kreteria yang diharapkan.

Tabel 2. Hasil Penilaian dengan Metode Baru

\begin{tabular}{|l|l|l|l|l|}
\hline \multirow{2}{*}{ No } & \multicolumn{3}{|c|}{ Penilaian } & \multirow{2}{*}{ Passing bawah } \\
\cline { 2 - 4 } & \multirow{2}{*}{$\begin{array}{l}\text { Sikap } \\
\text { awal }\end{array}$} & $\begin{array}{l}\text { Gerak } \\
\text { lanjutan }\end{array}$ & $\begin{array}{l}\text { Gerak } \\
\text { akhir }\end{array}$ & \\
\hline 1 & 3 & 4 & 4 & 11 \\
\hline 2 & 3 & 3 & 4 & 10 \\
\hline 3 & 3 & 3 & 3 & 9 \\
\hline 4 & 2 & 4 & 4 & 10 \\
\hline 5 & 2 & 3 & 4 & 9 \\
\hline 6 & 3 & 3 & 4 & 10 \\
\hline 7 & 4 & 3 & 4 & 11 \\
\hline 8 & 4 & 4 & 3 & 11 \\
\hline 9 & 3 & 3 & 4 & 10 \\
\hline 10 & 3 & 4 & 4 & 11 \\
\hline 11 & 3 & 3 & 4 & 10 \\
\hline 12 & 4 & 4 & 3 & 11 \\
\hline Jumlah & $\mathbf{3 7}$ & $\mathbf{4 1}$ & $\mathbf{4 5}$ & $\mathbf{1 2 3}$ \\
\hline$\%$ & $77 \%$ & $85 \%$ & $94 \%$ & $85 \%$ \\
\hline
\end{tabular}

Untuk menghitung rata-rata efektivitas metode baru dan baru pertama-tama harus ditentukan skor kriterium/ideal untuk sistem kerja tersebut.

Skor ideal $=1$ X 4 X 3 X $12=144$ dimana, $1=$ skor jawaban tertinggi

3 = tiga tahapan gerak (sikap awal, gerak lanjutan, gerak akhir) 
4 = empat butir instrumen

$12=$ jumlah responden

Selanjutnya skor ideal setiap butir instrumen

$=1 \mathrm{X} 4 \mathrm{X} 12=48$ dimana,

$1=$ skor jawaban tertinggi

$4=$ tahapan gerak

$12=12$ jumlah responden

Berdasarkan tabel 2 diperoleh jumlah data $=123$ Dengan demikian efektifitas metode mengajar baru secara keseluruhan = $123: 144=0,85$ atau $85 \%$ dari kreteria yang diharapkan.

Tabel 3. Perbandingan Sistem Kerja Lama dan Baru

\begin{tabular}{|l|l|l|}
\hline Metode & $\begin{array}{l}\text { Aspek-aspek } \\
\text { Penilaian } \\
\text { lama }\end{array}$ & $\begin{array}{l}\text { Metode } \\
\text { mengajar } \\
\text { baru }\end{array}$ \\
\hline $44 \%$ & $\begin{array}{l}\text { Sikap Awal passing } \\
\text { bawah }\end{array}$ & $77 \%$ \\
\hline $50 \%$ & $\begin{array}{l}\text { Gerak lanjutan } \\
\text { passing bawah }\end{array}$ & $85 \%$ \\
\hline $56 \%$ & $\begin{array}{l}\text { Gerakan akhir } \\
\text { passing bawah }\end{array}$ & $94 \%$ \\
\hline $50 \%$ & Rata-rata & $85 \%$ \\
\hline
\end{tabular}

Untuk membuktikan signifikansi perbedaan sistem kerja lama dan baru tersebut, perlu diuji secara statistik dengan $\mathrm{t}$ tes berkorelasi.

Tabel 4. Nilai-nilai Kinerja Sistem yang Dikorelasikan

\begin{tabular}{|c|c|c|}
\hline \begin{tabular}{|l|} 
No \\
\end{tabular} & $X_{1}$ & $X_{2}$ \\
\hline 1 & 5 & 11 \\
\hline 2 & 5 & 10 \\
\hline 3 & 7 & 9 \\
\hline 4 & 6 & 10 \\
\hline 5 & 6 & 9 \\
\hline 6 & 6 & 10 \\
\hline
\end{tabular}

\begin{tabular}{|l|l|l|}
\hline 7 & 7 & 11 \\
\hline 8 & 6 & 9 \\
\hline 9 & 7 & 11 \\
\hline 10 & 6 & 10 \\
\hline 11 & 5 & 10 \\
\hline 12 & 6 & 11 \\
\hline$\sum X$ & 72 & 123 \\
\hline $\bar{X}$ & 0,493 & 0,854 \\
\hline$S$ & 0.811 & 0.280 \\
\hline$S^{2}$ & 0.887364 & 0.665856 \\
\hline$r$ & 0.393 & 0.393 \\
\hline
\end{tabular}

Dalam penelitian ini dirumuskan hipotesis sebagai berikut:

Ho : efektvitas metode mengajar baru lebih kecil atau sama dengan metode mengajar lama

Ha : efektivitas metode mengajar baru lebih baik dari metode mengajar lama

$$
\begin{aligned}
& \text { Ho: } \mu_{1} \leq \mu_{2} \\
& \text { Ho }: \mu_{1}>\mu_{2}
\end{aligned}
$$

Pengujian dengan t-test berkorelasi uji fihak kanan. Menggunakan uji fihak kanan karena, hipotesis alternatf (Ha) berbunyi "lebih baik"

$$
\begin{aligned}
& t=\frac{\bar{x}_{1}-\bar{x}_{2}}{\sqrt{\frac{S_{1}^{2}}{n_{1}}+\frac{S_{2}^{2}}{n_{2}}-2 r\left(\frac{S_{1}}{\sqrt{n_{1}}}\right)\left(\frac{S 2}{\sqrt{n_{2}}}\right)}} \\
& t \\
& =\frac{0,811-0,280}{\sqrt{\frac{0.884}{12}+\frac{0,666}{12}}-2.0 .393\left(\frac{0,942}{\sqrt{12}}\right)\left(\frac{0,816}{\sqrt{12}}\right)} \\
& =-15.397
\end{aligned}
$$

Untuk membuat keputusan, apakah perbedaan itu signifikan atau tidak, maka harga $\mathrm{t}$ hitung tersebut perlu dibandingkan dengan harga $t$ tabel dengan $\mathrm{dk} n-2=10$, berdasarkan lampiran tabel II dalam nilainilai dalam distribusi t, bila dk 10 . Untuk uji coba satu fihak dengan taraf kesalahan 5\%, 
maka harga $\mathrm{t}$ tabel $=1,812$, harga $\mathrm{t}$ hitung jatuh pada daerah penerimaan $\mathrm{Ha}$, maka $\mathrm{Ha}$ yang menyatakan bahwa metode mengajar baru lebih baik dari metode mengajar lama diterima. Berdasarkan perhitungan ternyata $\mathrm{t}$ hitung - 15.397 jatuh pada penerimaan $\mathrm{Ha}$ atau penolakan Ho. Dengan demikian dapat disimpulkan bahwa terdapat perbedaan yang signifikan (dapat digeneralisasi) efektivitas metode mengajar baru dan lama, dimana metode mengajar baru lebih efektif dari metode mengajar lama.

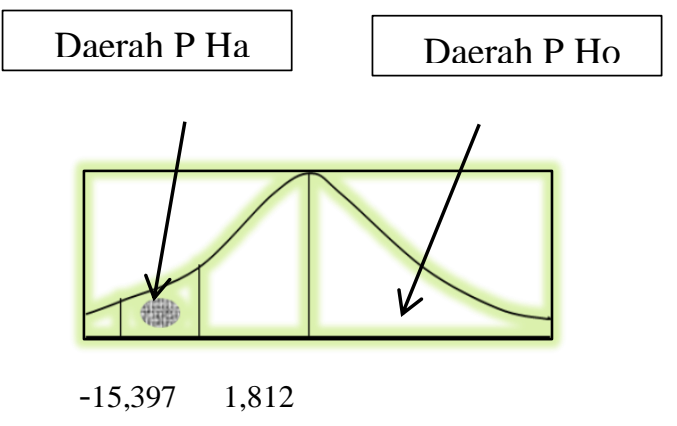

\section{Gambar 2. Uji hipotesis Fihak Kanan. $t$ hitung $\mathbf{- 1 5 , 3 9 7}$ jatuh pada daerah penerimaan Ha, sehingga Ha diterima.}

Tabel 5. Hasil Pengujian Tahap Kedua

\begin{tabular}{|c|l|l|l|l|}
\hline \multirow{2}{*}{ No } & \multicolumn{3}{|l|}{ Penilaian } & \multirow{2}{*}{ Jumlah } \\
\cline { 2 - 4 } & Passing bawah & \\
\hline & $\begin{array}{l}\text { Sikap } \\
\text { awal }\end{array}$ & $\begin{array}{l}\text { Gerak } \\
\text { lanjutan }\end{array}$ & $\begin{array}{l}\text { Gerak } \\
\text { akhir }\end{array}$ & \\
\hline 1 & 3 & 4 & 4 & 11 \\
\hline 2 & 3 & 3 & 4 & 10 \\
\hline 3 & 3 & 3 & 3 & 9 \\
\hline 4 & 2 & 4 & 4 & 10 \\
\hline 5 & 2 & 3 & 4 & 9 \\
\hline 6 & 3 & 3 & 4 & 10 \\
\hline 7 & 4 & 3 & 4 & 11 \\
\hline 8 & 4 & 4 & 3 & 11 \\
\hline 9 & 3 & 3 & 4 & 10 \\
\hline 10 & 4 & 4 & 4 & 12 \\
\hline 11 & 3 & 4 & 4 & 11 \\
\hline 12 & 3 & 3 & 4 & 10 \\
\hline 13 & 3 & 3 & 3 & 9 \\
\hline 14 & 2 & 4 & 4 & 10 \\
\hline 15 & 2 & 3 & 4 & 9 \\
\hline
\end{tabular}

\begin{tabular}{|l|l|l|l|l|}
\hline 16 & 3 & 3 & 4 & 10 \\
\hline 17 & 4 & 3 & 4 & 11 \\
\hline 18 & 4 & 4 & 3 & 11 \\
\hline 19 & 3 & 3 & 4 & 10 \\
\hline 20 & 4 & 4 & 4 & 12 \\
\hline 21 & 3 & 4 & 4 & 11 \\
\hline 22 & 3 & 3 & 4 & 10 \\
\hline 23 & 3 & 3 & 3 & 9 \\
\hline 24 & 2 & 4 & 4 & 10 \\
\hline 25 & 2 & 3 & 4 & 9 \\
\hline 26 & 3 & 3 & 4 & 10 \\
\hline 27 & 4 & 3 & 4 & 11 \\
\hline 28 & 4 & 4 & 3 & 11 \\
\hline 29 & 3 & 3 & 4 & 10 \\
\hline 30 & 4 & 4 & 3 & 11 \\
\hline Jumlah & 93 & 102 & 115 & 310 \\
\hline$\%$ & $77,5 \%$ & $85 \%$ & $96 \%$ & $86 \%$ \\
\hline
\end{tabular}

Untuk menghitung rata-rata efektivitas metode ini cara yang dilakukan sama dengan menghitung rata-rata efektivitas metode ini yaitu:

Skor ideal $=1$ X $3 \times 4 \times 30=360$ dimana,

$1=$ skor jawaban tertinggi.

$3=$ tiga tahapangerak

4 = empat instrumen

$30=$ jumlah responden

Selanjutnya skor ideal setiap butir instrumen $=1 \times 4 \times 30=120$.dimana,

$1=$ skor jawaban tertinggi

4 = empat instrumen

$30=30$ jumlah responden

Berdasarkan tabel 4.7 diperoleh jumlah data $=310$. Dengan demikian efektivitas metode mengajar secara keseluruhan $=310: 360=0,86$ atau $86 \%$ dari kriteria yang di harapkan

Tabel 6. Tingkat Kelulusan Siswa Menguasai Materi Pssing Bawah.

\begin{tabular}{|c|c|c|l|}
\hline Nilai & Katagori & Makna & Jumla \\
\hline$\geq 80$ & $\begin{array}{c}\text { Sangat } \\
\text { baik }\end{array}$ & Lulus & 24 \\
\hline $60-79$ & Baik & Lulus & 6 \\
\hline $40-59$ & Cukup & Tidak & \\
\hline
\end{tabular}




\begin{tabular}{|l|l|l|l|}
\hline $30-39$ & Kurang & $\begin{array}{l}\text { lulus } \\
\text { Tidak } \\
\text { lulus }\end{array}$ & \\
\hline$<29$ & $\begin{array}{l}\text { Sangat } \\
\text { kurang }\end{array}$ & $\begin{array}{l}\text { Tidak } \\
\text { lulus }\end{array}$ & \\
\hline Jumlah Siswa & $\mathbf{3 0}$ \\
\hline Jumlah Siswa Yang Lulus & $\mathbf{3 0}$ \\
\hline $\begin{array}{l}\text { Jumlah Siswa yang Tidak } \\
\text { Lulus }\end{array}$ & $\mathbf{0}$ \\
\hline
\end{tabular}

Berdasarkan tabel data nilai psikomotor di atas, didapat siswa yang memperoleh nilai $\geq 80$ (sangat baik) adalah 24 orang dan nilai 60-70 (baik) adalah 6 orang dan semua dinyatakan lulus, dengan demikian dapat disimpulkan bahwa materi Passing bawah telah berhasil dikuasai siswa.

Produk yang dikembangkan ini adalah bertujuan untuk membantu meningkatkan tercapainya tujuan pembelaran pendidikan jasmani khususnya materi passing bawah pada permainan bolavoli untuk siswa sekolah menengah pertama. Model ini dibuat berdasarkan tingkat kebutuhan anak dalam aktifitas gerak, yang mana secara psikologis anak-anak usia kelas VII ini lebih senang bermain dengan olahraga yang bersipat kompetisi, maka dalam model ini penerapannya dilakukan dengan prinsip permainan.

Hasil ujicoba tahap kedua penggunaan model ini ternyata menghasilkan $85 \%$ dari target yang di harapkan, artinya model ini sudah efektif untuk memenuhi kebutuhan pembelajaran Passing bawah dalam bolavoli untuk siswa sekolah menengah pertama.

\section{KESIMPULAN}

Berdasarkan data yang diperoleh, dari hasil uji coba lapangan dan pembahasan hasil penelitian, dapat disimpulkan bahwa, (1) Pengembangan model passing bawah bolavoli melalui pendekatan permainan tradisional, siswa dapat belajar secara efektif dan efisien. (2) Pengembangan model passing bawah bolavoli melalui pendekatan permainan tradisional yang telah peneliti kembangkan. Dapat disimpulkan bahwa terdapat perbedaan yang signifikan metode mengajar baru dan lama, dimana metode mengajar baru lebih efektif dari metode mengajar lama.

Produk pengembangan ini adalah pengembangan model passing bawah melalui pendekatan permainan tradisional yang dapat digunakan sebagai model mengajar oleh guru sekolah pertama. Dimana dalam pemanfaatanya perlu mempertimbangkan situasi, kondisi dan sarana prasarana.

\section{DAFTAR PUSTAKA}

Makmun, S. (1991). Psikologi Kependidikan Bandung: Bandung: Rosda Karya.

Arikunto, (1991). Prosedur Penelitia. Jakarta, Rineka Cipta,

Novi, (2008). Melatih bolavoli remaja. Lestari Yogyakarta: PT Citra Aji Parama.

Borg. W. R \& Gall,M. D. (1983). Educational Reseatch AnIntroduction. New York: Longman.

Dewyoga. D. Wasis. "Konsep Penelitian \& Pengembangan", Disajikan pada Lokakarya Metodologi Penelitian Jurusan Kepembelajaran Fakultas Ilmu Keolahragaan Universitas Negeri Semarang Malang.

Desmita. Psikologi Perkembangan Peserta Didik Paduan Bagi Orang Tua dan Guru dalam Memahami Psikologi Anak Usia SD,SMP dan SMA. Bandung. PT. Rosda Karya.

Nurhasan. (2007). Tes dan Pengukuran Keolahragaan, Bandung: Fakultas Pendidikan Olahraga dan kesehatan Universitas Pendidikan Indonesia.

Sugiyono. Metode Penelitian Kuantitatif, Kualitatif dan $R \quad \& \quad D$, Bandung:Alfabeta 
Sri mulyani. 45 permainan tradisional anak Indonesia, Langensari Publishing

Sadiman, Arif. (2003). Media Pendidikan Pengertian, Pengembangan, dan Pemampaatannya, Jakarta Pustekom Dikbud
Subroto, Toto. (2010). Didaktik Metodik Pembelajaran Olahraga Permainan, Prodi PJKR Fakultas Pendidikan Olahraga dan Kesehatan Universitas Pendidikan Indonesia. 